\title{
Oligella urethralis
}

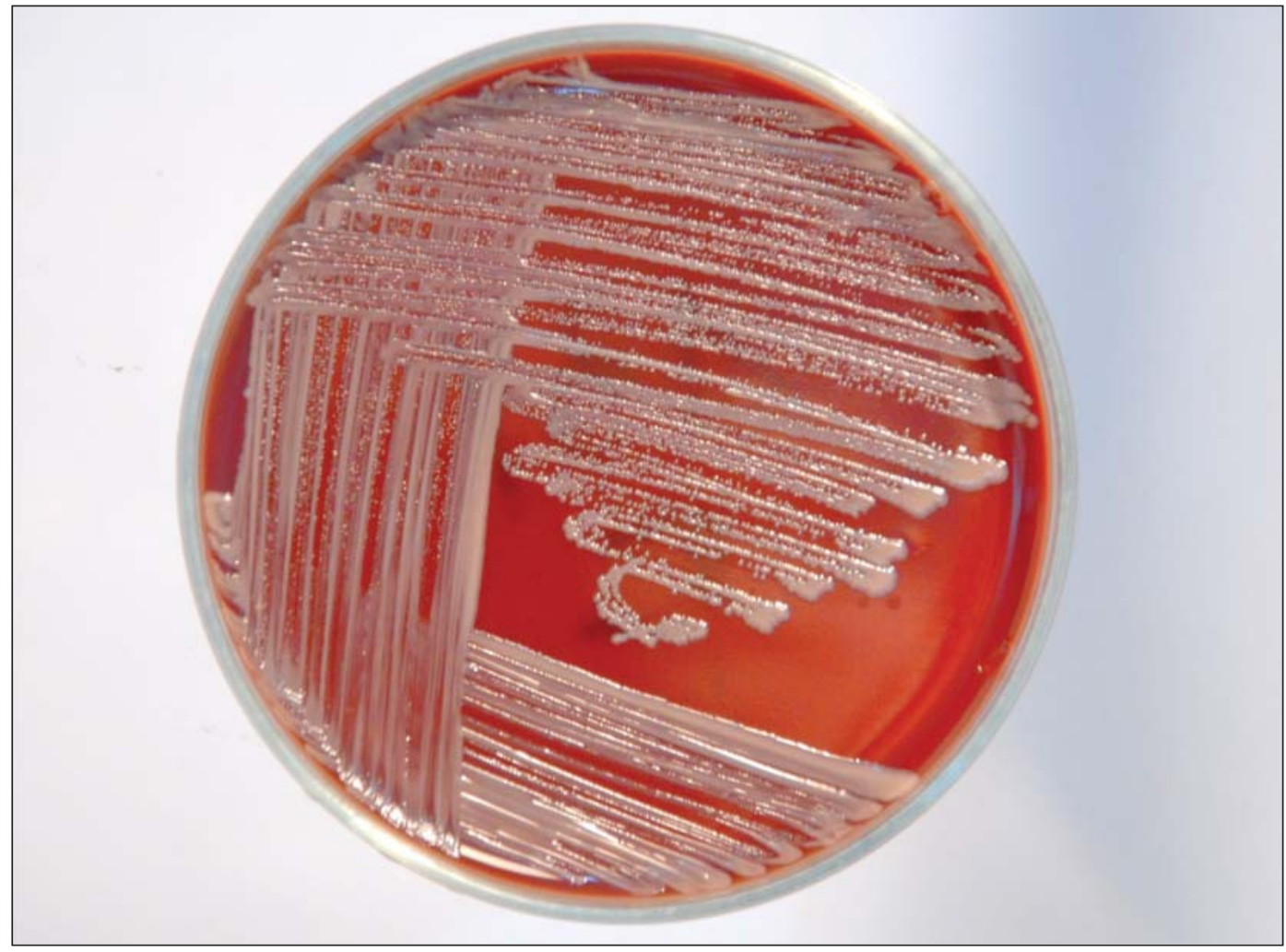

Figura 1. Cultivo de Oligella urethralis a las 72 h de incubación en agar sangre. 


\section{Oligella urethralis}

Oligella urethralis y Oligella ureolytica conforman el género Oligella perteneciente a la familia Alcaligenaceae. Son cocobacilos gramnegativos redondeados, no capsulados, dispuestos frecuentemente en pares. Crece en agar sangre produciendo colonias pequeñas de 2-3 mm, blanquecinas, opacas, circulares, convexas y no hemolíticas (Figura 1). O. urethralis crece bien en agar Mac Conkey. No oxidan ni fermentan los hidratos de carbono. Aerobios, catalasa y oxidasa positivo, no producen $\mathrm{H}_{2} \mathrm{~S}$, indol, no hidrolizan gelatina ó esculina. Reducen los nitritos, pero no los nitratos y su crecimiento en citrato de Simmons es variable. Oligella urethralis es ureasa negativa e inmóvil, lo que la distingue de O. ureolytica, que es móvil y ureasa positiva. En la galería API 20NE (Biomerieux ${ }^{\circledR}$ ), es indistinguible de Brevundimonas diminuta. Sin embargo, se distinguen claramente por su morfología, movilidad y sensibilidad a colistin (Tabla 1). Oligella spp. es susceptible a $\beta$-lactámicos y quinolonas. Se ha descrito la adquisición ocasional de resistencia a ambos grupos de antimicrobianos.

\begin{tabular}{|l|l|l|l|}
\hline \multicolumn{4}{|c}{ Tabla 1. Características fenotípicas que distinguen a O. urethralis, O. ureolytica y B. diminuta } \\
\hline Característica & O. urethralis & O. ureolytica & B. diminuta \\
\hline Morfología al Gram & Cocobacilos (cocoides) & Cocobacilos (cocoides) & Bacilos cortos y finos \\
\hline Movilidad & Inmóvil & Móvil por flagelos perítricos & Móvil por flagelo polar \\
\hline Ureasa & - & + & - \\
\hline Colistin (disco de $10 \mu \mathrm{g})$ & Sensible & Sensible & Resistente \\
\hline
\end{tabular}

Oligella urethralis forma parte de la microbiota comensal del tracto urogenital humano, especialmente en la mujer. Es patógeno oportunista aislado generalmente de infecciones urinarias y, con menor frecuencia, de bacteriemias con foco urinario, o artritis séptica.

\section{Referencias}

1.- Rossau R, Kersyers K, Falsen E, Jantzen E, Segers P, Union A, et al. Oligella, a new genus including Oligella urethralis comb.nov. (Formerly Moraxella urethralis) and Oligella ureolytica sp. nov. (Formerly CDC group IVe): relationship to Taylorella equigenitalis and related taxa. Int J Syst Bacteriol 1987; 37: 198-210.

María A. Martínez T. y Alfredo Ovalle S. Universidad de Chile, Santiago. Facultad de Medicina

Programa de Microbiología y Micología(MAMT)

Hospital San Borja Arriarán

Departamento de Obstetricia, Ginecología y Neonatología (AOS) 